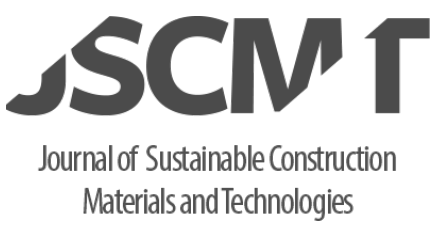

J Sustain. Construct. Mater. Technol. 5(1) (2020) 379-391 \begin{tabular}{c}
\hline \hline Journal of Sustainable \\
Construction Materials \\
and Technologies
\end{tabular}

www.eds.yildiz.edu.tr/jscmt

\title{
Preparations and Applications of Bio - Based Additives for Building Chemicals Production
}

\author{
Fulya Memioğlu ${ }^{\mathrm{a}, *}$, Murat Elibol $^{\mathrm{b}}$ \\ ${ }^{a}$ Graduate School of Natural and Applied Science, Biotechnology Program, Ege University, 35040, Izmir, Turkey \\ ${ }^{b}$ Bioengineering Department, Ege University, 35040, Bornova, Izmir, Turkey.
}

Manuscript Received November 19, 2019; Accepted January 9, 2020

\begin{abstract}
The objective of this report is to assess the effects of using olive oil mill wastewater (OMW) and cheese whey on the production of concrete chemical admixture. Wastewater samples were taken locally from two factories in Izmir. Concrete chemical admixture combinations (waste water, polycarboxylate, molasses, defoamer, biocide and water) at different ratios were generated with statistical experimental design methods and the effects of some parameters, such as level of chloride $(\%)$, solid content $(\%), \mathrm{pH}$, density $\left(\mathrm{gr} / \mathrm{cm}^{3}\right)$, were investigated. Furthermore, concrete tests were performed to identify slump $(\mathrm{cm})$ and strength $\left(\mathrm{kgf} / \mathrm{cm}^{2}\right)$ changes. The results showed that the addition of OMW and cheese whey up to $9.42 \%$ (wt) and $12.51 \%$ (wt), respectively can be potential admixture for concrete preparation, without loss of performance.
\end{abstract}

\section{Introduction}

Concrete, the most widely used construction material, is evolving. Nowadays, modern concrete which contains mineral components and chemical admixtures, is more complicated than a mixture of cement, water, and aggregates. Concrete chemical admixtures are used to make fresh and / or hardened concrete in desired properties. Amounts of admixtures are limited with 5\% percent of cement quantity in concrete mixtures and they are designed to work compatible with other components. Thus, it is possible to produce concrete which has high strength, freeze - thaw resistance and self - leveling properties.

It is known that construction chemicals market has an intense competition and a dynamic structure. Large part of production costs consists of domestic and import raw materials. In recent years, public concern about the environmental occurrence of consumer products has been increasing. As environmental consciousness is developing in our country, valorization of recycle or waste materials is preferred instead of producing conventional raw materials. Besides, R\&D projects from all over the world are focused on this concept.

Water pollution by chemicals has become a major source of concern and a priority for both society and public authorities, but more importantly, for the whole industrial world. What is water pollution? Water pollution can be defined in many ways. Pollution of water occurs when one or more substances that will modify the water in negative fashion are discharged in it. These substances can cause problems for people, animals and their habitats and also for the environment. The causes of water pollution are multiple: industrial wastes, mining activities,

\footnotetext{
${ }^{*}$ Corresponding author:

E-mail address: fulya.memioglu@gmail.com (F. Memioglu)
} 
sewage and waste water, pesticides and chemical fertilizers, energy use, radioactive waste, urban development etc [1].

Agro - industrial wastewaters include lignin, tannin, sugar and phenolic materials. Accumulation of unmanaged agro - wastewaters especially from the developing countries has an increased environmental risk. On the other hand, because setting up and plant operation of existing purification systems are costly, especially SMEs are exposed to difficult economical conditions. However, the valorization of such leftovers through the recovery and/or the biotransformation of their organic matter is a relevant opportunity, since it can combine the waste treatment to the production of added value chemicals [2]. The results obtained from the experiments clearly show that are agro - industrial wastewater has potential to develop cost effective concrete chemical admixtures. On the basis of these results, it is worth examining the incorporation of larger percentage of admixtures using agro - industrial wastewater.

\subsection{Olive Mill Waste Waster}

Olive oil production is concentrated mainly in Mediterranean countries: Spain, Italy, Greece, Turkey, Syria, Tunisia and Morocco [3]. About $1.8 \times 10^{6} \mathrm{t}$ of olive oil are produced worldwide every year [4]. Olive mill waste water (OMW) is the aqueous waste derived from the production of virgin oil [5]. Nowadays, three kinds of oil extraction systems are used around the world, namely: the pressure process (olive presses), 2 - phases decanter separation and 3 - phases decanter separation. Two phase systems are fully implemented in Spain and in Cyprus, while Greece, Tunisia, and Italy still use both systems, but mainly 3 - phase ones. Two phase systems generate a paste - like waste called 'alperujo' or ' 2 - phase pomace'. Two phase systems have a low polluting charge since they consume $15 \mathrm{~kg}$ water per $100 \mathrm{~kg}$ olive processed [6]. The 3 - phase system generates two main residues: A solid residue named olive mill solid waste (OMSW) or olive husk and a liquid effluent named olive mill waste water (OMWW) (Fig 1) [7]. The average amount of olive mill wastewater (OMWW) produced during the milling process is $1,2-1,8 \mathrm{~m}^{3} / \mathrm{t}$ of olives, thus generating over 30 million $\mathrm{m}^{3}$ of OMWW per year and in the Mediterranean region [6].

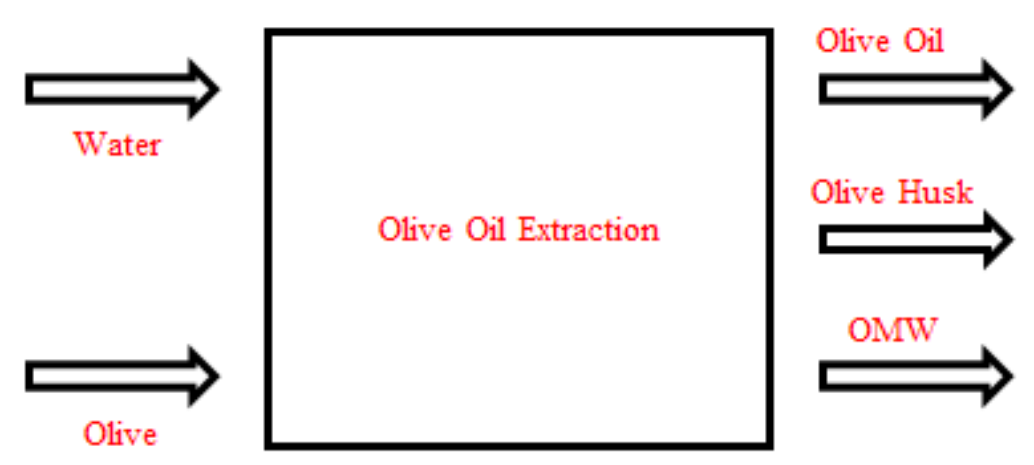

Fig. 1. Relationship between formation of OMW and the remaining constituents presents in olive oil extraction

\subsection{Cheese Whey}

Milk is one of the most consumed food products in the world, and since the 60 s its presence in human diet has doubled worldwide [8]. The dairy industry processes fresh milk in a variety of ways and manufactures derived products such as butter, ice cream, cheese, yogurt, desserts, milk powder, etc. To a greater or lesser extent, these dairy derivatives are made and consumed worldwide [9]. According to the Food and Agriculture Organization (FAO), world milk production is estimated to reach 859 million tons in 2019 [8].

Dairy wastewater can be divided into three major categories: i) treatment of the water used in the cooling and heating processes, (ii) treatment of the wastewaters produced by cleaning the equipment and spillage products after separation of secondary products such as milk powder and pressing, and (iii) sanitary wastewater, which is typically piped directly to sewer system. The diary wastewater production volumes and characteristics, due to the diversity of industries, techniques, processes, and equipment are quite variable. Generally, diary washing water 
containing a high amount of organic material, an alkaline surfactant, and acidic chemicals that after the cleaning of bottles and tanks are disposed to the environment. Cheese whey is a liquid that remains after separation of protein and fat by coagulation of milk. This liquid contains lactose $(70-75 \%)$ and soluble proteins $(10-15 \%)$ with a high chemical oxygen demand $\left(\mathrm{COD}=50,000-70,000 \mathrm{mgL}^{-1}\right)$. Whey is usually dried in the factory and used as feedstock for animal feeding, food additive, and pharmaceutical compounds. The cheese whey wastewater contain a heterogeneous group of proteins comprised of about $50 \% \beta$ - lactoglobulin, $18 \% \alpha-$ lactalbumin, $5 \%$ bovine serum albumin, $10 \%$ immunoglobulin, and $17 \%$ protease peptones,lactoferrin, and miscellaneous proteins. The final COD after mixing the whey wastewater with the washing waters results in a diluted effluent with $2000-4000 \mathrm{mgL}^{-1}$ of COD that requiring treatment before discharge of the environment. Also, the presence of ammonium nitrogen (NH4+ - N) between 60 and $270 \mathrm{mgL}^{-1}$ has harmful effects on aquatic media. Regarding the presence of organic carbon and nitrogen in whey wastewater, the treatment of this wastewater is of great importance. Physico - chemical and biological treatment methods have been proposed for dairy wastewater treatments. In the physical - chemical process, protein and fat precipitations remove some parts of the organic load using various chemical compounds. In this regard, biological processes are generally preferred, because of low soluble COD removal and the high cost of some treatment materials in physical chemical treatment processes. Various aerobic and anaerobic biological treatments are often used for dairy wastewater treatments. Nevertheless, biological treatments proposed for dairy wastewater treatment have some drawbacks in field applications such as high content of organic matter, high sludge production in aerobic treatments, and presence of fats. Therefore, it is necessary to solve the problems in dairy wastewater treatment $[10]$.

Many recent studies have been devoted to the valorization of agro - food by - products in order to address sustainable and environmental requirements. However, the recovery of target components from waste implies the use of downstream and purification processes which are time consuming and costly as well as not environmentally friendly due to the use of huge amounts of water. An alternative approach consists of exploiting agro - waste without any pretreatment, with the aim of preparing multifunctional materials, the development of which is indeed of great interest now for the industry, which is always looking for high - performance products obtainable through simple and low - cost [5].

The aim of this study is to synthesis concrete chemical admixtures that have high strength and slump values, with agro - industrial waste waters (OMW and cheese whey). For this purpose, concrete chemical admixtures were synthesized via different combinations generated randomly using statistical experimental design method. After the characterization processes, the results were analyzed to obtain optimum combination of admixture.

\section{Experimental materials and methods}

\subsection{Materials}

OMW and cheese whey were collected from Orpir Oil Company and Pinar Süt Company. All the chemicals such as polycarboxylate, molasses, defoamer and biocide used were in technical grade and supplied by INKA Chemical Company, Izmir, Türkiye.

\subsection{Sample preparation (Synthesis of chemical concrete admixtures)}

To reduce the number of experiments despite the large number of variables, method of statistical experimental design was used. For this purpose, a software, 'Design Expert 7.0 Trial Version' was used. The parameters which are thought to have effect on the experiments were determined. Thereafter, 'Response Surface Methodology (RSM)' and its sub - option 'Central Composite Design (CCD)' were selected. Minimum maximum ranges of parameters were defined in the program. In this way, experimental combinations were created randomly. The levels of experimental variables are presented at Table 1 and Table 2 for OMW and cheese whey, respectively. Limit values were determined for polycarboxylate $(18-21 \% \mathrm{wt})$, molasses $(0-10$ $\% \mathrm{wt})$ and defoamer $(0-0.18 \% \mathrm{wt})$. Amount of biocide was kept constant. To understand the effectivenesses of OMW and cheese whey, reference samples were prepared without waste waters.

At experimental section, firstly, water was weighed and then mixed with polycarboxylate, molasses, defoamer, and biocide, respectively. At this step, wastewater including OMW or cheese whey was added. After stirring with homogenizer (Silverson L4RT - $8000 \mathrm{rpm}$ ) for $5 \mathrm{~min}$, the mixture was left to rest. The experiments were performed at room temperature $\left(25^{\circ} \mathrm{C}\right)$. 
Table 1. Combinations of chemical concrete admixtures including OMW

\begin{tabular}{|c|c|c|c|c|c|c|}
\hline No & Polycarboxylate (\% wt) & $\begin{array}{c}\text { Molasses } \\
(\% \text { wt })\end{array}$ & $\begin{array}{c}\text { OMW (\% } \\
\text { wt) }\end{array}$ & Defoamer (\% wt) & Biocide (\% wt) & Water $(\% \mathrm{wt})$ \\
\hline $\mathrm{D} 0 *$ & 21.00 & 10.00 & - & 0.18 & 0.20 & 68.62 \\
\hline D1 & 18.00 & 10.00 & 3.18 & - & 0.20 & 68.62 \\
\hline D2 & 18.00 & 10.00 & 3.00 & 0.18 & 0.20 & 68.62 \\
\hline D3 & 19.50 & 5.00 & 6.68 & - & 0.20 & 68.62 \\
\hline D4 & 18.00 & - & 13.00 & 0.18 & 0.20 & 68.62 \\
\hline D5 & 18.00 & - & 13.18 & - & 0.20 & 68.62 \\
\hline D6 & 21.00 & 5.00 & 5.09 & 0.09 & 0.20 & 68.62 \\
\hline D7 & 19.50 & 5.00 & 6.59 & 0.09 & 0.20 & 68.62 \\
\hline D8 & 19.50 & 10.00 & 1.59 & 0.09 & 0.20 & 68.62 \\
\hline D9 & 21.00 & - & 10.18 & - & 0.20 & 68.62 \\
\hline D10 & 21.00 & 10.00 & 0.18 & - & 0.20 & 68.62 \\
\hline D11 & 21.00 & - & 10.00 & 0.18 & 0.20 & 68.62 \\
\hline D12 & 18.00 & 5.00 & 8.09 & 0.09 & 0.20 & 68.62 \\
\hline D13 & 19.50 & 5.00 & 6.50 & 0.18 & 0.20 & 68.62 \\
\hline D14 & 19.50 & - & 11.59 & 0.09 & 0.20 & 68.62 \\
\hline
\end{tabular}

D0* Reference sample

Table 2. Combinations of chemical concrete admixtures including cheese whey

\begin{tabular}{|c|c|c|c|c|c|c|}
\hline No & $\begin{array}{l}\text { Polycarboxylate } \\
\text { (\% wt) }\end{array}$ & $\begin{array}{l}\text { Molasses } \\
(\% \text { wt })\end{array}$ & $\begin{array}{l}\text { Defoamer } \\
(\% \mathrm{wt})\end{array}$ & $\begin{array}{l}\text { Biocide } \\
(\% \text { wt })\end{array}$ & $\begin{array}{l}\text { Cheese whey } \\
(\% \mathrm{wt})\end{array}$ & $\begin{array}{l}\text { Water } \\
(\% \mathrm{wt})\end{array}$ \\
\hline D0* & 21.00 & 10.00 & 0.18 & 0.20 & - & 68,62 \\
\hline D1 & 18.00 & 10.00 & 0.18 & 0.20 & 3.18 & 68,44 \\
\hline D2 & 19.50 & 5.00 & 0.09 & 0.20 & 6.59 & 68,62 \\
\hline D3 & 21.00 & - & - & 0.20 & 10.18 & 68,62 \\
\hline D4 & 19.50 & 5.00 & - & 0.20 & 6.68 & 68,62 \\
\hline D5 & 18.00 & 10.00 & 0.18 & 0.20 & 3.00 & 68,62 \\
\hline D6 & 19.50 & 10.00 & 0.09 & 0.20 & 1.59 & 68,62 \\
\hline D7 & 21.00 & 5.00 & 0.09 & 0.20 & 5.09 & 68,62 \\
\hline D8 & 19.50 & 5.00 & 0.09 & 0.20 & 6.59 & 68,62 \\
\hline D9 & 18.00 & 5.00 & 0.09 & 0.20 & 8.09 & 68,62 \\
\hline D10 & 18.00 & - & 0.18 & 0.20 & 13.00 & 68,62 \\
\hline D11 & 21.00 & - & 0.18 & 0.20 & 10.00 & 68,62 \\
\hline D12 & 19.50 & 5.00 & 0.18 & 0.20 & 6.50 & 68,62 \\
\hline D13 & 21.00 & 10.00 & - & 0.20 & 0.18 & 68,62 \\
\hline D14 & 18.00 & - & - & 0.20 & 13.18 & 68,62 \\
\hline D15 & 19.50 & - & 0.09 & 0.20 & 11.59 & 68,62 \\
\hline D16 & 18.00 & 10.00 & - & 0.20 & 3.18 & 68,62 \\
\hline
\end{tabular}

D0* Reference sample

\subsection{Characterization of chemical concrete admixtures}

Synthesized concrete chemical admixtures were characterized by using FTIR (Agilent Cary 630 FTIR 
Instrument), $\mathrm{pH}$ meter (Metler Toledo), chloride content (Titroline 5000 Chloride Otomatic Titration device), solid content (Precisa $330 \mathrm{XM}$ ) - $0.01 \mathrm{~g}$ ), density (Isolab piknometer - $100 \mathrm{ml}$ ), Pan mixer (Utest - $56 \mathrm{~L}$ ), standart slump test equipment (Utest), sample pool equipped with heat control (Utest) and concrete press (Utest $-3000 \mathrm{kN})$.

The constituents of mixtures were cement, water, fine aggregate, coarse aggregate and chemical additive. Portland cement was used. The composition of the concrete mixes is shown in Table 3 . The preparation and the cure of all the mixes were conducted in the Inka Construction Chemicals Company in Izmir, Türkiye. All mixing was conducted under laboratory conditions. The sand, cement and coarse aggregates were placed and dry-mixed for about 2 min before water was added. After 3 min of mixing followed when water was added, a slump test was run to determine its workability. The mixture in each group was cast in $15 \times 15 \times 15 \mathrm{~mm}$ cubes moulds. They were demolded a day after casting and were cured in a curing pool for land 28 days. The specimens were kept in the curing pool, left one day in room conditions to dry out and tested using press for strength.

Table 3. Mixture proportions of concrete

\begin{tabular}{ll}
\hline Components & $\%(w t)$ \\
\hline W/C & 0,53 \\
Superplasticizer Additive $(\%)$ & $\% 1,20$ \\
Water & 7 \\
Portland Cement $42,5-$ CEM II & 14 \\
Aggregate $(0-3 \mathrm{~mm})$ & 21 \\
Aggregate $(0-5 \mathrm{~mm})$ & 19 \\
Aggregate $(5-12 \mathrm{~mm})$ & 17 \\
Aggregate $(11-25 \mathrm{~mm})$ & 22 \\
Concrete Unit Weight & $\sim 2,96 \mathrm{gr} / \mathrm{cm} 3$ \\
\hline
\end{tabular}

\section{Results and discussion}

Experimental design and optimization are tools used to systematically examine different types of problems that arise within, e.g., research, development and production. It is obvious that if experiments are performed randomly, the results obtained will also be random. Therefore, it is a necessity to plan the experiments in such a way that the interesting information will be obtained [11]. For all sample compositions, one or more components were decreased and waste waters were added at equal quantity.

Fig 2 illustrates FTIR results obtained for concrete admixtures prepared with OMW or cheese whey. Concrete admixtures both containing OMW or cheese whey showed three broad peak areas which were located at 1030 $1160 \mathrm{~cm}^{-1}, 1520-1775 \mathrm{~cm}^{-1}$ and $2790-3750 \mathrm{~cm}^{-1}$. The peaks at between 1030 and $1160 \mathrm{~cm}^{-1}$ mean revealing the heterogeneous chemical nature of these biomasses [12]. The results showed that the presence of the $\mathrm{O}-\mathrm{H}$ hydroxyls groups $\left(3700 \mathrm{~cm}-1\right.$ and $\left.3100 \mathrm{~cm}^{-1}\right)$, aromatic CHar $\left(3100-3000 \mathrm{~cm}^{-1}\right)$, aliphatic CH (2942 and 2887 $\mathrm{cm}^{-1}$ ), as well as $\mathrm{C}=\mathrm{O}$ of the carboxylic acid at $1717 \mathrm{~cm}^{-1}$ associated by hydrogen bond and conjugate $\mathrm{C}=\mathrm{O}$ of the flavonoids at $1650 \mathrm{~cm}^{-1}$ [13]. 


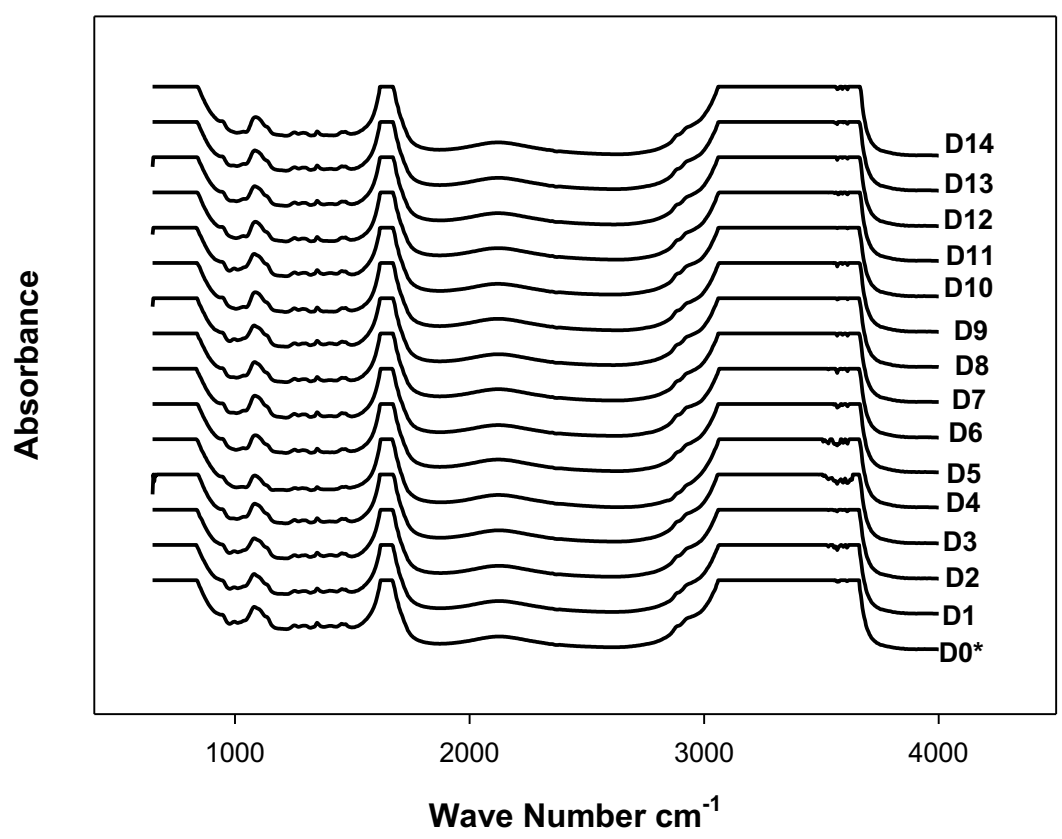

(a)

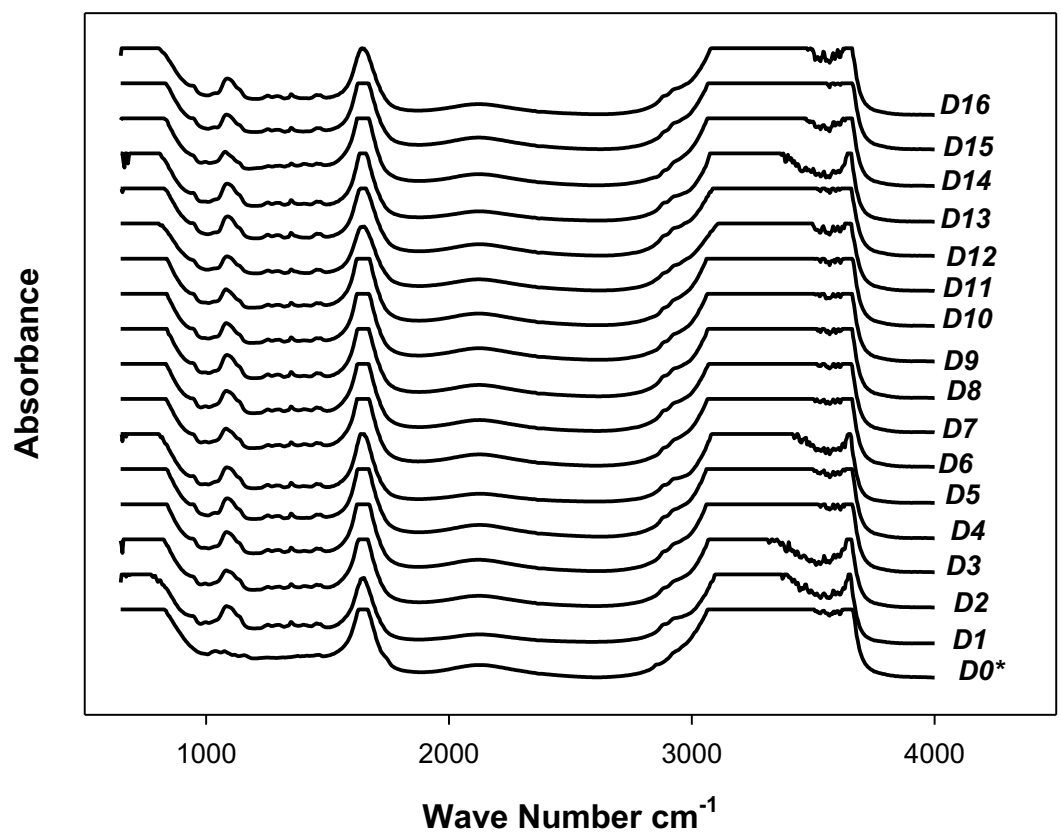

(b)

Fig. 2. FTIR Spectra of concrete chemical admixtures with (a) OMW; (b) Cheese whey

The experimental results for mixture combinations with OMW and cheese whey are given in Table 4 and Table 5, respectively. $\mathrm{pH}$, density, amounts of chloride and solid content changed with waste water concentrations. 
Table 4. Results of chemical concrete admixtures including OMW

\begin{tabular}{|c|c|c|c|c|}
\hline OMW (\%) & Amount of chloride (\%) & Amount of solid content $(\%)$ & $\mathrm{pH}$ & Density $\left(\mathrm{gr} / \mathrm{cm}^{3}\right)$ \\
\hline 0.18 & 0.0602 & 16.90 & 4.49 & 1.04 \\
\hline 6.68 & 0.0360 & 14.07 & 4.30 & 1.03 \\
\hline 11.59 & 0.0195 & 12.24 & 4.25 & 1.02 \\
\hline- & 0.0538 & 18.07 & 4.44 & 1.04 \\
\hline 8.09 & 0.0442 & 13.93 & 4.56 & 1.03 \\
\hline 6.59 & 0.0506 & 14.01 & 4.29 & 1.03 \\
\hline 6.59 & 0.0506 & 14.01 & 4.29 & 1.03 \\
\hline 6.50 & 0.0384 & 14.65 & 4.37 & 1.03 \\
\hline 13.18 & 0.0241 & 11.24 & 4.06 & 1.02 \\
\hline 3.00 & 0.0599 & 16.46 & 4.48 & 1.03 \\
\hline 6.59 & 0.0506 & 14.01 & 4.29 & 1.03 \\
\hline 6.59 & 0.0506 & 14.01 & 4.29 & 1.03 \\
\hline 10.00 & 0.0250 & 27.87 & 4.21 & 1.02 \\
\hline 6.59 & 0.0506 & 14.01 & 4.29 & 1.03 \\
\hline 1.59 & 0.0578 & 16.73 & 4.45 & 1.04 \\
\hline 13.00 & 0.0264 & 11.37 & 4.05 & 1.02 \\
\hline 3.18 & 0.0572 & 16.16 & 4.46 & 1.04 \\
\hline 10.18 & 0.0226 & 11.20 & 3.98 & 1.02 \\
\hline 6.59 & 0.0506 & 14.01 & 4.29 & 1.03 \\
\hline 5.09 & 0.0379 & 15.31 & 4.24 & 1.03 \\
\hline
\end{tabular}

Table 5. Results of chemical concrete admixtures including cheese whey

\begin{tabular}{|c|c|c|c|c|}
\hline Cheese Whey (\% wt) & $\begin{array}{l}\text { Amount of } \\
\text { chloride (\%) }\end{array}$ & $\begin{array}{c}\text { Amount of solid } \\
\text { content }(\%)\end{array}$ & $\mathrm{pH}$ & (Density $\left(\mathrm{gr} / \mathrm{cm}^{3}\right)$ \\
\hline 8.09 & 0.08 & 12.44 & 4.41 & 1.029 \\
\hline 6.59 & 0.09 & 12.28 & 4.10 & 1.043 \\
\hline 13.00 & 0.03 & 10.17 & 2.95 & 1.012 \\
\hline 0.18 & 0.07 & 13.03 & 4.08 & 1.033 \\
\hline 6.68 & 0.06 & 12.66 & 4.21 & 1.032 \\
\hline 11.59 & 0.02 & 10.83 & 2.87 & 1.026 \\
\hline 3.18 & 0.10 & 15.32 & 4.44 & 1.038 \\
\hline 10.00 & 0.02 & 11.47 & 2.99 & 1.025 \\
\hline 6.59 & 0.06 & 13.62 & 4.10 & 1.025 \\
\hline 13.18 & 0.03 & 10.91 & 2.92 & 1.027 \\
\hline- & 0.11 & 17.77 & 4.31 & 1.044 \\
\hline 10.18 & 0.02 & 12.04 & 2.85 & 1.022 \\
\hline 1.59 & 0.08 & 15.85 & 4.39 & 1.037 \\
\hline 3.18 & 0.07 & 17.71 & 4.34 & 1.043 \\
\hline 5.09 & 0.05 & 13.41 & 4.05 & 1.027 \\
\hline 6.50 & 0.07 & 15.11 & 4.26 & 1.032 \\
\hline
\end{tabular}


It was seen that combination of polycarboxylate and molasses were more effective for density and $\mathrm{pH}$ than combination of polycarboxylate and defoamer. For solid content, interactions were not clear. For chloride content, it was increasing with molasses. Defoamer and polycarboxylate had no effect for chloride content. Slump is one of the significant parameters for concrete performance. However, slump changed depending on molasses and polycarboxylate excessively. Increasing the concentration of OMW and cheese whey diminished the slump values (Fig 3).

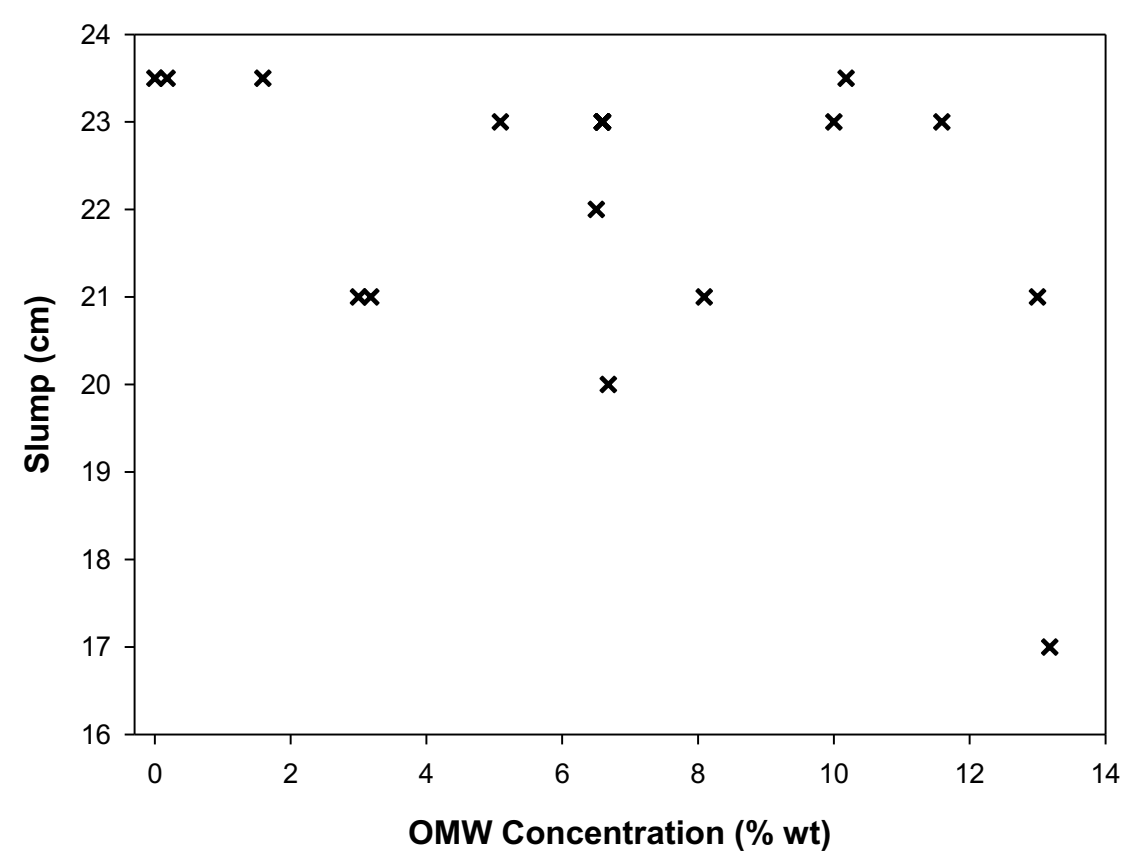

(a)

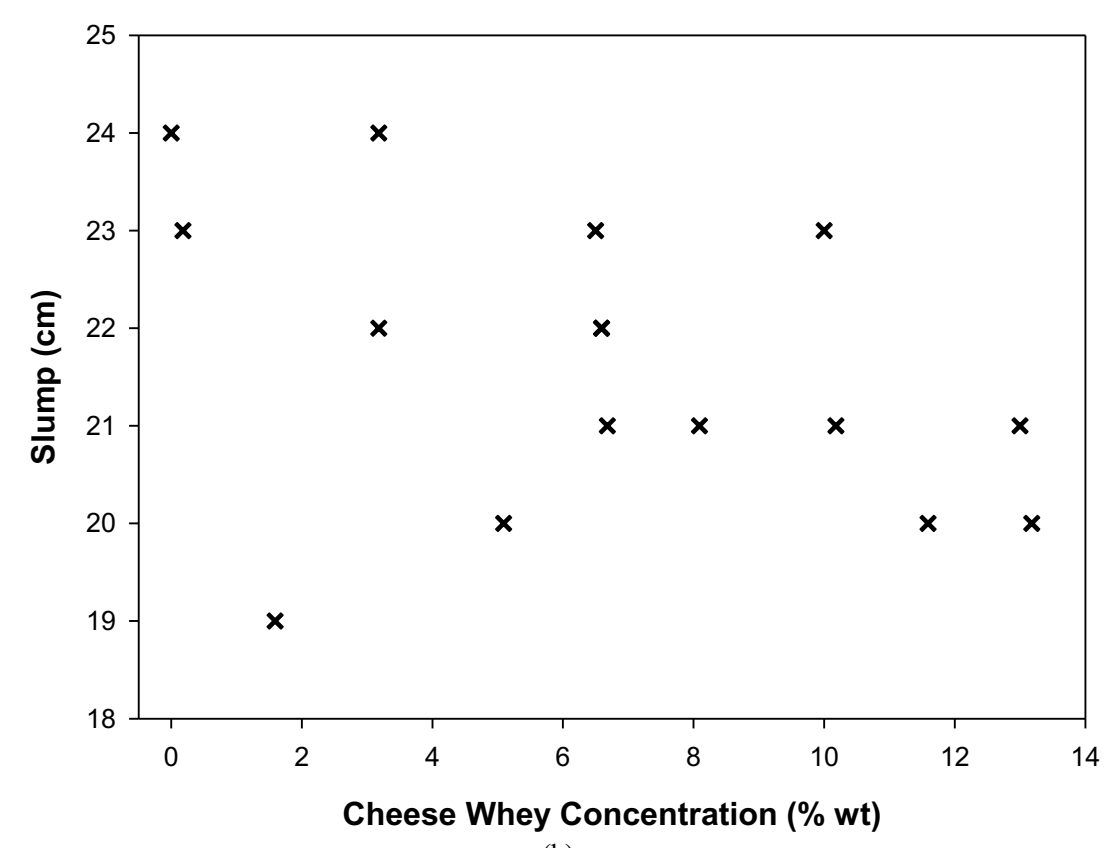

(b)

Fig. 3. The interactions between slump (cm) and (a) OMW concentration (\% wt); (b) cheese whey concentration (\% wt) 
Self - compacting concrete is cast far away from the facilities where the concrete produce. To keep the workability without lack of strength, water reducer components were used. Polycarboxylate, molasses and defoamer had little effect on strength for fresh concrete (Fig 4) compared with strength (28. day). It was assumed that the strength

is

almost

stable

after

28

days.

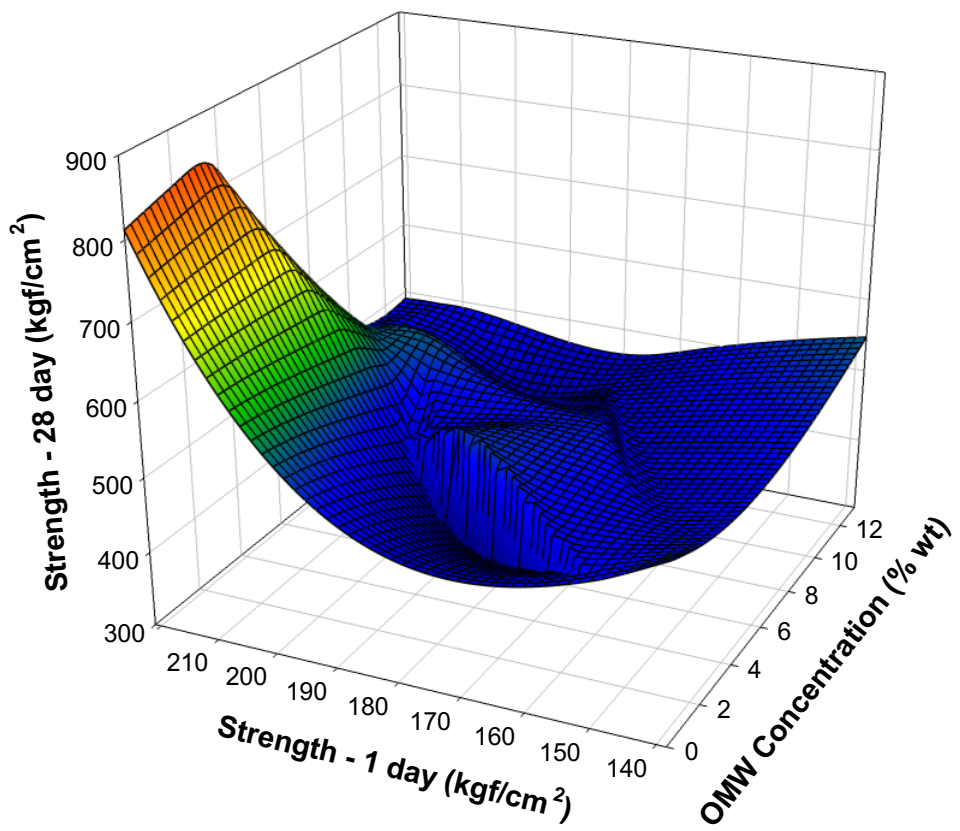

(a)

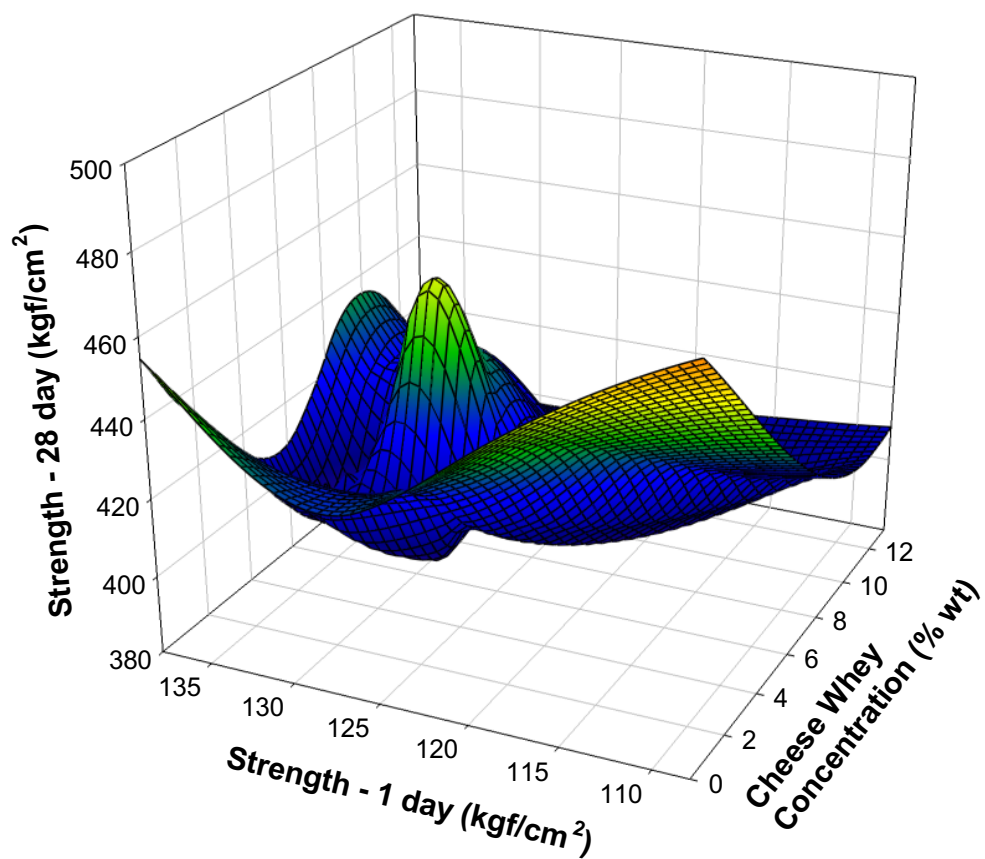

(b)

Fig. 4. 3D plots of the interactions between strength -1 day $\left(\mathrm{kgf} / \mathrm{cm}^{2}\right)$ and strength -28 day $\left(\mathrm{kgf} / \mathrm{cm}^{2}\right)$ variables and (a) OMW concentration $(\% \mathrm{wt}) ;(\mathrm{b})$ cheese whey concentration $(\% \mathrm{wt})$ 
The optimum options and prediction of their results for OMW, derived from the optimization process with the software, are given Table $6-7$. OMW concentrations were found between 8.00 and $9.42 \%$ wt. Desirability was varied from 0.74 to 0.77 .

Table 6. Optimum combinations of chemical concrete admixtures including OMW

\begin{tabular}{ccccccc} 
No & $\begin{array}{c}\text { Polycarboxylate } \\
(\% \mathrm{wt})\end{array}$ & $\begin{array}{c}\text { Molasses } \\
(\% \mathrm{wt})\end{array}$ & $\begin{array}{c}\text { OMW } \\
(\% \mathrm{wt})\end{array}$ & $\begin{array}{c}\text { Defoamer } \\
(\% \mathrm{wt})\end{array}$ & $\begin{array}{c}\text { Biocide } \\
(\% \mathrm{wt})\end{array}$ & Water $(\% \mathrm{wt})$ \\
\hline 1 & 21.00 & 1.10 & 8.90 & 0.18 & 0.20 & 68.62 \\
2 & 21.00 & 1.03 & 8.97 & 0.18 & 0.20 & 68.62 \\
3 & 21.00 & 0.98 & 9.02 & 0.18 & 0.20 & 68.62 \\
4 & 20.98 & 0.60 & 9.42 & 0.18 & 0.20 & 68.62 \\
5 & 20.90 & 1.38 & 8.72 & 0.18 & 0.20 & 68.62 \\
6 & 21.00 & 1.08 & 8.93 & 0.18 & 0.20 & 68.61 \\
7 & 20.57 & 1.17 & 9.26 & 0.18 & 0.20 & 68.62 \\
\hline
\end{tabular}

Table 7. Predictions for optimum combinations of chemical concrete admixtures including OMW

\begin{tabular}{ccccccccc}
\hline No & $\begin{array}{c}\text { Strength } \\
-1 \text { day } \\
\left(\mathrm{kgf} / \mathrm{cm}^{2}\right)\end{array}$ & $\begin{array}{c}\text { Strength } \\
-28 \text { day } \\
\left(\mathrm{kgf} / \mathrm{cm}^{2}\right)\end{array}$ & $\begin{array}{c}\text { Amount of } \\
\text { chloride }(\%)\end{array}$ & $\begin{array}{c}\text { Amount of } \\
\text { solid content } \\
(\%)\end{array}$ & $\mathrm{pH}$ & $\begin{array}{c}\text { Density } \\
\left(\mathrm{gr} / \mathrm{cm}^{3}\right)\end{array}$ & $\begin{array}{c}\text { Slump } \\
(\mathrm{cm})\end{array}$ & Desirability \\
\hline 1 & 216.67 & 507.93 & 0.03 & 23.97 & 4.21 & 1.02 & 23.14 & 0.77 \\
2 & 216.61 & 507.18 & 0.03 & 24.02 & 4.21 & 1.02 & 23.16 & 0.77 \\
3 & 216.50 & 506.49 & 0.03 & 24.06 & 4.21 & 1.02 & 23.18 & 0.77 \\
4 & 215.78 & 501.59 & 0.02 & 24.26 & 4.19 & 1.02 & 23.30 & 0.77 \\
5 & 215.45 & 509.64 & 0.03 & 23.30 & 4.22 & 1.02 & 23.03 & 0.76 \\
6 & 214.32 & 507.04 & 0.03 & 23.64 & 4.21 & 1.02 & 23.28 & 0.76 \\
7 & 211.51 & 502.67 & 0.03 & 21.90 & 4.20 & 1.02 & 22.97 & 0.75 \\
\hline 8 & 210.62 & 515.06 & 0.03 & 21.00 & 4.24 & 1.03 & 22.64 & 0.74 \\
\hline
\end{tabular}

The results for admixtures containing cheese whey are given in Table 7. All responses were affected by the factors selected (cheese whey, polycarboxylate, molasses and defoamer concentrations). It was clear that density values were more stable against polycarboxylate and defoamer than molasses. $\mathrm{pH}$ was not sensitive for defoamer - polycarboxylate interaction. Solid content was changed depending on the interaction between defoamer and molasses. Similarly, chloride content was increasing with molasses. Because of high chloride content induces the bar corrosion, low values were preferable. Slump values stayed nearly stable for molasses. The results show that strength values (1. day and 28. day) had main effect for molasses concentration.

The optimum combinations and their results for cheese whey are concluded at Table $8-9.23$ options were suggested by the software considering desirability levels. While cheese whey concentration was up to $12.51 \%$, molasses is descended to $0 \%$. Strength (28. day), slump and density were equal for all options. 
Table 8. Optimum combinations of chemical concrete admixtures including cheese whey

\begin{tabular}{|c|c|c|c|c|c|c|}
\hline No & Polycarboxylate (\% wt) & Molasses (\% wt) & Cheese whey (\% wt) & $\begin{array}{c}\text { Defoamer } \\
(\% \mathrm{wt})\end{array}$ & Biocide (\% wt) & $\begin{array}{l}\text { Water } \\
(\% \mathrm{wt})\end{array}$ \\
\hline 1 & 21.00 & - & 9.97 & 0.18 & 0.20 & 68.65 \\
\hline 2 & 21.00 & - & 9.97 & 0.18 & 0.20 & 68.65 \\
\hline 3 & 20.82 & - & 10.15 & 0.18 & 0.20 & 68.65 \\
\hline 4 & 20.78 & - & 10.19 & 0.18 & 0.20 & 68.65 \\
\hline 5 & 20.99 & 0.10 & 9.88 & 0.18 & 0.20 & 68.65 \\
\hline 6 & 20.79 & - & 10.18 & 0.18 & 0.20 & 68.65 \\
\hline 7 & 21.00 & - & 9.98 & 0.17 & 0.20 & 68.65 \\
\hline 8 & 21.00 & 0.29 & 9.69 & 0.18 & 0.20 & 68.64 \\
\hline 9 & 21.00 & - & 9.99 & 0.17 & 0.20 & 68.64 \\
\hline 10 & 21.00 & 0.17 & 9.81 & 0.17 & 0.20 & 68.65 \\
\hline 11 & 20.11 & - & 10.87 & 0.18 & 0.20 & 68.64 \\
\hline 12 & 19.96 & - & 11.03 & 0.18 & 0.20 & 68.63 \\
\hline 13 & 19.81 & - & 11.18 & 0.18 & 0.20 & 68.63 \\
\hline 14 & 19.61 & - & 11.38 & 0.18 & 0.20 & 68.63 \\
\hline 15 & 19.33 & - & 11.66 & 0.18 & 0.20 & 68.63 \\
\hline 16 & 19.14 & - & 11.86 & 0.18 & 0.20 & 68.62 \\
\hline 17 & 18.77 & - & 12.22 & 0.18 & 0.20 & 68.63 \\
\hline 18 & 18.67 & - & 12.33 & 0.18 & 0.20 & 68.62 \\
\hline 19 & 18.35 & 0.24 & 12.42 & 0.18 & 0.20 & 68.61 \\
\hline 20 & 18.41 & 0.09 & 12.51 & 0.16 & 0.20 & 68.63 \\
\hline 21 & 18.01 & 0.53 & 12.49 & 0.17 & 0.20 & 68.60 \\
\hline 22 & 18.00 & 4.43 & 8.73 & - & 0.20 & 68.64 \\
\hline 23 & 18.00 & 4.12 & 9.04 & 0.02 & 0.20 & 68.62 \\
\hline
\end{tabular}

Compared the predictionof sample composition including OMW and cheese whey, it was seen that, additive formulations prepared with OMW contained molasses more than cheese whey's. On the other hand, sample with OMW had higher strength at 1 . day and 28. day. Although, it seems that slump values were close each other, sample of additives was not sensitive. 
Table 9. Predictions for optimum combinations of chemical concrete admixtures including cheese whey

\begin{tabular}{|c|c|c|c|c|c|c|c|c|}
\hline No & $\begin{array}{l}\text { Strength } \\
-1 \text { day } \\
\left(\mathrm{kgf} / \mathrm{cm}^{2}\right)\end{array}$ & $\begin{array}{l}\text { Strength - } \\
28 \text { day } \\
\left(\mathrm{kgf} / \mathrm{cm}^{2}\right)\end{array}$ & $\begin{array}{l}\text { Amount of } \\
\text { chloride } \\
(\%)\end{array}$ & $\begin{array}{l}\text { Amount of } \\
\text { solid } \\
\text { content }(\%)\end{array}$ & $\mathrm{pH}$ & $\begin{array}{l}\text { Density } \\
\left(\mathrm{gr} / \mathrm{cm}^{3}\right)\end{array}$ & $\begin{array}{l}\text { Slump } \\
(\mathrm{cm})\end{array}$ & Desirability \\
\hline 1 & 127.56 & 415.56 & 0.03 & 11.77 & 2.98 & 1.02 & 21.63 & 0.61 \\
\hline 2 & 127.56 & 415.56 & 0.03 & 11.77 & 2.98 & 1.02 & 21.63 & 0.61 \\
\hline 3 & 127.56 & 415.56 & 0.03 & 11.65 & 2.98 & 1.02 & 21.63 & 0.61 \\
\hline 4 & 127.56 & 415.56 & 0.03 & 11.62 & 2.98 & 1.02 & 21.63 & 0.61 \\
\hline 5 & 127.56 & 415.56 & 0.03 & 11.83 & 3.02 & 1.02 & 21.63 & 0.60 \\
\hline 6 & 127.56 & 415.56 & 0.03 & 11.63 & 2.97 & 1.02 & 21.63 & 0.60 \\
\hline 7 & 127.56 & 415.56 & 0.03 & 11.77 & 2.97 & 1.02 & 21.63 & 0.60 \\
\hline 8 & 127.56 & 415.56 & 0.03 & 11.94 & 3.09 & 1.02 & 21.63 & 0.60 \\
\hline 9 & 127.56 & 415.56 & 0.03 & 11.76 & 2.97 & 1.02 & 21.63 & 0.60 \\
\hline 10 & 127.56 & 415.56 & 0.03 & 11.86 & 3.04 & 1.02 & 21.63 & 0.60 \\
\hline 11 & 127.56 & 415.56 & 0.03 & 11.18 & 2.96 & 1.02 & 21.63 & 0.60 \\
\hline 12 & 127.56 & 415.56 & 0.03 & 11.07 & 2.96 & 1.02 & 21.63 & 0.60 \\
\hline 13 & 127.56 & 415.56 & 0.03 & 10.97 & 2.95 & 1.02 & 21.63 & 0.60 \\
\hline 14 & 127.56 & 415.56 & 0.03 & 10.83 & 2.95 & 1.02 & 21.63 & 0.60 \\
\hline 15 & 127.56 & 415.56 & 0.03 & 10.64 & 2.95 & 1.02 & 21.63 & 0.59 \\
\hline 16 & 127.56 & 415.56 & 0.03 & 10.51 & 2.95 & 1.02 & 21.63 & 0.59 \\
\hline 17 & 127.56 & 415.56 & 0.03 & 10.27 & 2.94 & 1.02 & 21.63 & 0.59 \\
\hline 18 & 127.56 & 415.56 & 0.03 & 10.20 & 2.94 & 1.02 & 21.63 & 0.59 \\
\hline 19 & 127.56 & 415.56 & 0.04 & 10.17 & 3.03 & 1.02 & 21.63 & 0.58 \\
\hline 20 & 127.56 & 415.56 & 0.03 & 10.17 & 2.97 & 1.02 & 21.63 & 0.57 \\
\hline 21 & 127.56 & 415.56 & 0.04 & 10.25 & 3.13 & 1.02 & 21.63 & 0.56 \\
\hline 22 & 127.56 & 415.56 & 0.06 & 12.56 & 4.21 & 1.03 & 21.63 & 0.50 \\
\hline 23 & 127.56 & 415.56 & 0.06 & 12.50 & 4.15 & 1.03 & 21.63 & 0.50 \\
\hline
\end{tabular}

\section{Conclusion}

Agro - industrial sector, especially olive oil mills, is emergently looking for sustainable solutions to valorize waste waters and reduce their environmental impact. To this end, the performance of the concrete chemical admixtures synthesized with OMW and cheese whey were investigated.

Response surface methodology proved to be useful tool in developing optimum combinations for concrete chemical additives contains OMW and cheese whey. Routine parameters of additives such as amount of chloride (\%), amount of solid content (\%), $\mathrm{pH}$ and density $\left(\mathrm{g} / \mathrm{cm}^{3}\right)$ were near to each other for both OMW and cheese whey. On the other hand, strength $\left(\mathrm{kgf} / \mathrm{cm}^{2}\right)$ and slump $(\mathrm{cm})$ values were judged as essential responses.

The software program offered 8 and 23 optimum options for concrete chemical additives with OMW and cheese whey, respectively. According to result, optimum area for additives with OMW was more specific than cheese whey's. In this field there are opportunities but it should be further explored by researcher to reach results for exact optimum points.

\section{Acknowledgements}


The authors declare that they have no known competing financial interests or personal relationships that could have appeared to influence the work reported in this paper.

\section{References}

1. G. Crini and E. Lichtfouse. "Advantages and Disadvantages of Techniques Used for Wastewater Treatment". Environmental Chemistry Letter 17 (2019) $145-155$

2. A. Scoma, L. Bertin, G. Zanaroli, S. Fraraccio, F. Fava. “A Physicochemical - Biotechnological Approach for An Integrated Valorization of Olive Mill Wastewater'. Bioresource Technology 102 (2011) 10273 - 10279.

3. W. Yassine, S. Zyade, S. Akazdam, A. Essadki, B. Gourich and D. Benmessaoud. "A Study of Olive Mill Waste Water Removal by A Biosorbent Prepared by Olive Stones', Mediterranean Journal of Chemistry 8(5) (2019) 420 - 434.

4. K. Haddad, M. Jeguirim, B. Jerbi, A. Chouchene, P. Dutournie, N. Thevenin and et al. "'Olive Mill Wastewater: From a Pollutant to Green Fuels, Agricultural Water Source and Biofertilizer’. ACS Sustainable Chemistry \& Engineering 5 (2017) 8988 - 8996.

5. L. Sisti, G. Totaro, N. Bozzi Ciorci, D. Di Gioia, A. Celli, V. Verney, F. Leroux. 'Olive Mill Waste Water Valorization in Multifunctional Biopolymer Composites for Antibacterial Packaging Application'. International Journal of Molecular Sciences. 20 (2019) 2376.

6. M. Jeguirim, P. Dutournie, A. A. Zorpas, L. Limousy. "Olive Mill Waste Water: From A Pollutant to Green Fuels, Agricultural Water Sources and Bio - Fertilizer - Part 1". The drying kinetics. Energies. 10 (2017) 1423.

7. C. Rocha, M. A. Soria, L. M. Madeira. "Thermodynamic Analysis of Olive Oil Mill Wastewater Steam Reforming”. Journal of the Energy Institute xxx (2018) $1-11$.

8. M. Lastra-Mejias, A. Villa-Martinez, M. Izquierdo, R. Aroca-Santos, J. C. Cancilla, J. S. Torrecilla. "Combination of LEDs and Cognitive Modeling to Quantify Sheep Cheese Whey in Watercourses’. Talanta, 203 (2019) 290-296.

9. M. Izquierdoa, A. Villa-Martineza, M. Lastra-Mejiasa, R. Aroca-Santosa, J. C. Cancillab, J. S. Torrecillaa, “'Intelligent Real - Time Quantification of Cheese Whey in Rivers and Reservoirs in Madrid (Spain)". Sensors and Actuators B: Chemical 298 (2019).

10. B. Mohebrad, A. Rezaee, B. Sohrabi. "Effect of Isoelectric Point on Cheese Whey Wastewater Treatment Using a Microbial Electrochemical System', Bioelectrochemistry. 130 (2019) 107200.

11. T. Lundstedt, E. Seifert, L. Abramo, B. Thelin, A. Nystrom, S. Petterson and et al. "Experimental Design and Optimization". Chemometrics and Intelligent Laboratory Systems 42 (1998) 3-40

12. M. R. Provenzano, G. Iannuzi, C. Fabbri and N. Senesi. "Qualitative Characterization and Different of Digestates from Different Biowastes Using FTIR and Fluorescence Spectroscopies”. Journal of Environmental Protection 2 (2011) 83 - 89.

13. B. Zghari, P. Doumena, A. Romane and A. Boukir. "GC-MS, FTIR and 1H ,13C NMR Structural Analysis and Identification of Phenolic Compounds in Olive Mill Wastewater Extracted from Oued Oussefrou Effluent (Beni Mellal-Morocco)', J. Mater. Environ. Sci 8 (2017) 4496 - 4509 